\title{
Bacillary Angiomatosis in HIV-Infected Patients - An Epidemiological and Clinical Study
}

\author{
A. Plettenberg ${ }^{\text {a }}$ T. Lorenzen ${ }^{a}$ B.T. Burtsche ${ }^{a}$ H. Rasokat ${ }^{d}$ T. Kaliebe ${ }^{e}$ \\ H. Albrecht ${ }^{b}$ T. Mertenskötter ${ }^{c} \quad$ J.R. Bogner ${ }^{f} \quad$ A. Stoehr ${ }^{a} \quad$ H. Schöferg \\ aAllgemeines Krankenhaus St. Georg, bUniversitätskrankenhaus Eppendorf, und 'Bernhard-Nocht-Institut, \\ Hamburg, dUniversitätshautklinik Köln, e Krankenhaus Schwabing, München und ${ }^{\mathrm{f}}$ Medizinische Poliklinik, \\ Universität München, und gUniversitätshautklinik Frankfurt/Main, Deutschland
}

\section{Key Words}

Bacillary angiomatosis · HIV infection · Bartonella

Rochalimaea. AIDS

\begin{abstract}
Background: No data were available on the epidemiological and clinical characteristics of bacillary angiomatosis (BA) in Germany. Objective: To determine epidemiological and clinical data on HIV-associated BA. Methods: A chart review of all BA cases between 1990 and 1998 was performed in 23 German AIDS treatment units. Results: A total of 21 cases of BA was diagnosed. During this period, the participating HIV centers treated about 17,000 HIV-infected patients. As a result, a BA prevalence of 1.2 cases/1,000 patients can be assumed. 19 BA were localized in the skin; in 5 cases bones and in 4 cases the liver were involved. Out of 20 patients who received antibiotic therapy, 13 had complete remission. The median time of duration up to complete remission was 32 days (9-82). During the follow-up of the 20 patients, 7 relapses were observed. Conclusion: BA is a rare HIV-associated disease with a prevalence of 1,2 cases/1,000 patients in the presented study.
\end{abstract}

Copyright @ 2000 S. Karger AG, Basel

\section{Introduction}

Bacillary angiomatosis (BA), also termed epithelioid angiomatosis, is an angioproliferative disease first described in 1983 by Stoler et al. [1]. It has occurred most commonly in patients with severe immunosuppression caused by the human immunodeficiency virus (HIV). BA has only rarely been discovered in patients with other kinds of immunosuppression, such as organ transplant recipients or immunocompromised individuals [2, 3]. The disease derived its name from the vascular proliferation seen in histological tissue examination and from the presence of numerous bacillary organisms detectable in Warthin-Starry silver staining or electron microscopy [4] (fig. 1c). In recent years, molecular biological techniques, which allow for an exact pathogen typing, have become established [5] (fig. 1d).

The first described clinical manifestation of an infection with organisms of the Rochalimaea genus (now known as Bartonella) was called 'trench fever' as it appeared among the battlefield troops in World War I [6]. In 1990, Relman et al. [7] recognized a relationship between the 'trench fever' microorganism and the bacterium Rochalimaea quintana (now Bartonella quintana), the agent of BA. In 1992, another member of the genus Bar-

Priv.-Doz. Dr. Andreas Plettenberg

Allgemeines Krankenhaus St. Georg, Infektionsambulanz/Haus Z

Lohmühlenstrasse 5

D-20099 Hamburg (Germany)

Tel. +49 402890 2283, Fax +49 402890 3404, E-Mail Plettenberg@compuserve.com 

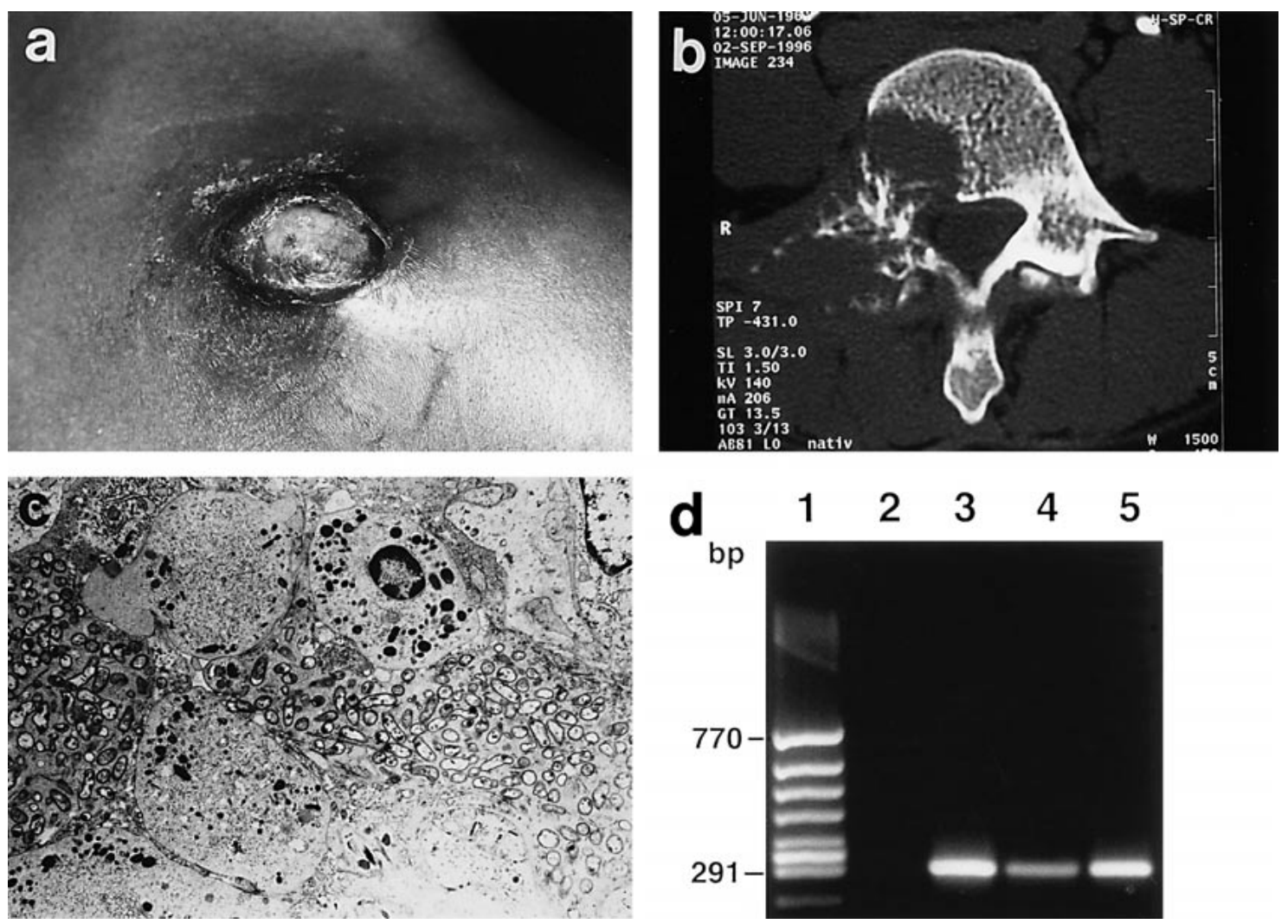

Fig. 1. 53-year-old HIV-infected patient with BA manifestations of the skin, liver, bones and pancreas as well as pronounced general symptoms and a weight loss of $15 \mathrm{~kg}$. The patient was treated with $2 \mathrm{~g} /$ day of erythromycin per os for 12 weeks. This therapy led to a complete remission of all lesions and an increase in weight by $18 \mathrm{~kg}$. Until the time of evaluation (12 months after the end of the therapy), the patient had no relapse of BA. a A $3 \times 5 \mathrm{~cm}$ ulcerated nodule on the patient's shoulder which, later, was completely excised surgically. $\mathbf{b}$ The lytic bone lesion of a thoracic vertebra. c The tissue from a under an electron microscope. Multiple bacteria can be seen with the form and wall structure characteristic of the Bartonella group pathogen. d The polymerase chain reaction in the focus from a. Lane 1: DNA molecular size markers; lane 2: negative control; lane 3; positive control; lane 4: EDTA blood of the described patient; lane 5: tissue of the lesion shown in $\mathbf{a}$.

tonella, $B$. henselae, was also recognized to be associated with this illness [8]. BA typically presents itself as an inflammatory disease, most often involving the skin. $\mathrm{Cu}-$ taneous lesions may be solitary or multiple and can be localized superficially, in the skin or subcutaneously (fig. 1a). In addition, oral, anal, conjunctival and gastrointestinal mucosal surfaces, as well as the liver, bones, lymph nodes, spleen and several other organs may be involved (fig. 1b). These lesions grow slowly over a period of several weeks. In patients afflicted with this disorder, other symptoms like fever, loss of weight or an overall feeling of illness typically appear. On histological examination, lesions of BA consist of lobular proliferations of small blood vessels containing plump, cuboidal endothe- lial cells. These are interspersed with mixed inflammatory cell infiltrates having a predominance of neutrophils [9]. Because of the infrequent occurrence of BA, there is no uniform scheme of therapy, but, in patients with HIV infections, experienced clinicians recommend antibiotic treatment with oral erythromycin or doxycycline over a period of 8-12 weeks [10].

In 1993, the first cases of BA were described in Germany $[11,12]$. Although a few cases were reported during the following years [13], no synopsis of the different BA infections in Germany was carried out.

Consequently, we conducted a retrospective investigation with various centers of the German AIDS Study Group to obtain epidemiological and clinical data on 
HIV-associated BA in Germany. To our knowledge, this study describes the largest published series of HIVinfected patients with BA in a clearly characterized region of Europe.

\section{Methods}

We conducted a retrospective multicenter study in Germany in order to analyze epidemiological and clinical data of patients with HIV-associated BA. 23 German HIV centers (see appendix) associated with the German AIDS Study Group (GASG/IdkF) participated in this evaluation. Standardized data on the medical histories of all HIV-infected patients with BA were gathered in the period form January 1,1990 , to December 31, 1998. To verify the diagnosis of BA there had to be typical clinical manifestations in combination with histological findings of respective bacteria in Warthin-Starry staining or electron microscopy or identification of the Bartonella species by molecular biological techniques. General demographic data were analyzed as well as details of clinical manifestation and diagnosis of BA, treatment and clinical outcome. This study was conducted with the support of the AIDS-Center of the Robert Koch Institute/Bundesministerium für Gesundheit file 415-4476-09/25.

\section{Results}

Between 1990 and 1998, 23 HIV centers associated with the GASG/IdkF treated a total of 17,626 HIVinfected patients. During this period, 21 cases of BA were documented. The prevalence of BA was therefore 11.9 cases/10,000 HIV-infected patients. Of these 21 patients, 19 were male and 2 female. The median age was 39 years (26-71 years). Nineteen patients (90\%) had CD4-positive lymphocytes less than 100 cells $/ \mu$, but 2 had distinctly more than 300 cells $/ \mu 1(350,405$ cells $/ \mu 1)$. The median CD 4 cell count was 30 cells $/ \mu \mathrm{l}(0-405$ cells $/ \mu \mathrm{l})$. According to the classification of the Centers for Disease Control, in 13 of the 21 individuals the stage of the HIV infection was $\mathrm{C}$ (AIDS), in 6 patients B3 and in 2 B2. Nine patients had been afflicted with Kaposi's sarcoma in their medical history, 6 with Pneumocystis carinii pneumonia and 4 patients with cytomegalovirus infections; in 4 cases, esophageal candidiasis had been diagnosed and 2 patients had cerebral toxoplasmosis.

In 18 cases, the diagnosis of BA was verified by Warthin-Starry staining, in 4 patients electron microscopy was performed and in 3 patients molecular biological methods were applied.

In 19 out of the 21 patients with BA the skin was involved, in 5 cases the bones were infected and 4 patients had manifestations in the liver. Three of the individuals had BA of the lymph nodes. In 2 patients, the mucous membranes were involved. One patient had a manifestation of the spleen and another of the central nervous system (table 1).

In the cases of cutaneous BA, the median number of lesions was $9(1-80)$. In 12 cases, they were localized at the lower extremities, in 11 patients at the upper extremities, 8 patients had manifestations of the trunk, another 8 on the head and 2 patients had mucocutaneous manifestations of the oral cavity.

All 19 patients with cutaneous manifestations had dermal papules or nodules; 8 cases showed additionally ulceration and crusting. In 4 patients, plaques were described. Systemic symptoms were documented in 11 patients: the symptoms involved fever in 9 patients, weight loss in 3 and nighttime sweating in 4 cases. Only 11 patients were found to have had contact with cats. In 10 cases, no contact with cats was documented. One patient owned a cat but denied being scratched. Out of 21 patiens with BA, 20 received antibiotic therapy. In 15 patients, erythromycin was used; 2 patients received doxycyline, while 3 other patients were each treated with amoxillin/clavulanic acid, cefuroxime and imipenem. Thirteen patients had a complete remission, while in 7 patients only a partial response was observed. The median duration of treatment was 28 days (5-240 days). The median time needed to achieve a complete response was 36 days (19-240 days). However, 3 patients with a complete response and 4 patients with a partial response had a relapse after antibiotic therapy. Four of the 7 patients with relapses were treated with erythromycin; each was treated with imipenem, amoxicillin and cefuroxime. The antibiotic therapy of the 7 patients lasted a median of 21 days (13-88 days). After completion of the antibiotic therapy, the median time of relapse was 5 weeks (3-16 weeks).

Up to the time of evaluation, 7 patients had died (fig. 2). The median duration between time of diagnosis of BA and death was 8 months (0-34 months). One of these patients died from peliosis hepatis with dissemination to multiple organs including the lungs and the bones before therapy could be initiated. Although the patient did not present any skin lesions that could have suggested BA, the infection was diagnosed on autopsy. In the other deceased patients, the shortest time between diagnosis of BA and death was 2 months. In none of these 6 cases was BA the cause of death. All patients died from other complications of their HIV infection. $\overline{328} \quad \overline{\text { Dermatology 2000;201:326-331 }}$
Plettenberg/Lorenzen/Burtsche/Rasokat/ Kaliebe/Albrecht/Mertenskötter/Bogner/ Stoehr/Schöfer 
Fig. 2. Kaplan-Meyer analysis of the surviv-

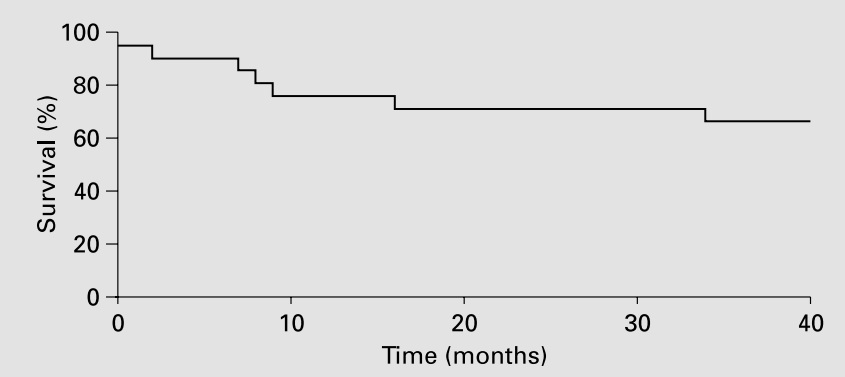
al of the 21 described patients with BA.

Table 1. Demographic and clinical data of 21 patients with BA

\begin{tabular}{|c|c|c|c|c|c|c|c|c|}
\hline $\begin{array}{l}\text { Patient } \\
\text { No. }\end{array}$ & $\begin{array}{l}\text { Age } \\
\text { years }\end{array}$ & Sex & $\begin{array}{l}\mathrm{CDC} \\
\text { stage }\end{array}$ & $\begin{array}{l}\text { CD4 cells } \\
\times 10^{6} / 1\end{array}$ & Involved organs & Diagnostics & Antibiotic therapy & Outcome \\
\hline 1 & 28 & M & $\mathrm{C} 3$ & 31 & Skin, lymph node & $\mathrm{HE}$ & $\begin{array}{l}\text { Erythromycin, } \\
6 \text { weeks }\end{array}$ & $\mathrm{CR}$, no relapse \\
\hline 2 & 40 & M & $\mathrm{C} 3$ & 20 & $\begin{array}{l}\text { Liver, bone, } \\
\text { lymph node }\end{array}$ & WS, HE & No therapy & $\begin{array}{l}\text { Died before therapy } \\
\text { could be initiated }\end{array}$ \\
\hline 3 & 53 & $\mathrm{M}$ & $\mathrm{C} 3$ & 57 & Skin & WS, HE & $\begin{array}{l}\text { Erythromycin, } \\
8 \text { weeks }\end{array}$ & $\mathrm{CR}$, no relapse \\
\hline 4 & 35 & M & B3 & 34 & Skin & WS, HE, EM, PCR & $\begin{array}{l}\text { Erythromycin, } \\
13 \text { weeks }\end{array}$ & $\mathrm{CR}$, no relapse \\
\hline 5 & 35 & $\mathrm{M}$ & $\mathrm{C} 3$ & 10 & Skin, bone & HE, PCR & $\begin{array}{l}\text { Erythromycin, } \\
4 \text { weeks }\end{array}$ & $\mathrm{PR}$, no relapse \\
\hline 6 & 56 & M & $\mathrm{C} 2$ & 406 & Skin & WS, HE, EM & $\begin{array}{l}\text { Erythromycin, } \\
5 \text { weeks }\end{array}$ & $\mathrm{CR}$, no relapse \\
\hline 7 & 28 & $\mathrm{M}$ & $\mathrm{C} 3$ & 15 & Skin & WS, HE & $\begin{array}{l}\text { Erythromycin, } \\
5 \text { weeks }\end{array}$ & $\mathrm{CR}$, no relapse \\
\hline 8 & 49 & $\mathrm{M}$ & $\mathrm{C} 3$ & 20 & Skin, CNS & WS, HE, EM & $\begin{array}{l}\text { Erythromycin, } \\
19 \text { days }\end{array}$ & $\begin{array}{l}\mathrm{CR} \text {, relapse after } \\
5 \text { weeks }\end{array}$ \\
\hline 9 & 45 & M & $\mathrm{C} 3$ & 13 & Skin, bone & WS, HE & $\begin{array}{l}\text { Erythromycin, } \\
6 \text { weeks }\end{array}$ & $\begin{array}{l}\text { CR, relapse } 6 \text { weeks } \\
\text { after end of therapy }\end{array}$ \\
\hline 10 & 32 & $\mathrm{M}$ & B3 & 10 & Skin & WS, HE & $\begin{array}{l}\text { Cefuroxime, } \\
3 \text { weeks }\end{array}$ & $\begin{array}{l}\text { PR, relapse } 6 \text { weeks } \\
\text { after end of therapy }\end{array}$ \\
\hline 11 & 29 & M & $\mathrm{C} 3$ & 14 & Skin, lymph node & WS, HE, EM & $\begin{array}{l}\text { Doxycycline, } \\
34 \text { weeks }\end{array}$ & $\mathrm{CR}$, no relapse \\
\hline 12 & 41 & M & B3 & 60 & Skin & WS & $\begin{array}{l}\text { Erythromycin, } \\
3 \text { weeks }\end{array}$ & $\begin{array}{l}\text { CR, relapse } 3 \text { weeks } \\
\text { after end of therapy }\end{array}$ \\
\hline 13 & 73 & W & B3 & 70 & Skin & WS & $\begin{array}{l}\text { Erythromycin, } \\
3 \text { weeks }\end{array}$ & $\mathrm{CR}$, no relapse \\
\hline 14 & 52 & M & $\mathrm{C} 3$ & 70 & Skin & WS, HE & $\begin{array}{l}\text { Erythromycin, } \\
3 \text { weeks }\end{array}$ & $\mathrm{CR}$, no relapse \\
\hline 15 & 39 & M & $\mathrm{C} 3$ & 30 & Skin & WS, HE & $\begin{array}{l}\text { Amoxicillin, } \\
3 \text { weeks }\end{array}$ & $\begin{array}{l}\text { PR, relapse } 3 \text { weeks } \\
\text { after end of therapy }\end{array}$ \\
\hline 16 & 28 & W & B2 & 34 & Skin, liver & WS, HE, PCR & $\begin{array}{l}\text { Erythromycin, } \\
3 \text { weeks }\end{array}$ & $\mathrm{CR}$, no relapse \\
\hline 17 & 40 & M & B3 & 10 & $\begin{array}{l}\text { Skin, liver, } \\
\text { mucous membrane }\end{array}$ & WS, HE & $\begin{array}{l}\text { Erythromycin, } \\
12 \text { weeks }\end{array}$ & $\begin{array}{l}\text { PR, relapse after } \\
16 \text { weeks }\end{array}$ \\
\hline 18 & 31 & $\mathrm{M}$ & $\mathrm{C} 3$ & 20 & Skin, bone & WS, HE & $\begin{array}{l}\text { Imipenem, } \\
13 \text { days }\end{array}$ & $\begin{array}{l}\text { PR, relapse } 8 \text { weeks } \\
\text { after end of therapy }\end{array}$ \\
\hline 19 & 28 & $\mathrm{M}$ & B3 & 49 & Skin & WS, HE & $\begin{array}{l}\text { Erythromycin, } \\
3 \text { weeks }\end{array}$ & $\mathrm{PR}$, no relapse \\
\hline 20 & 33 & M & B2 & 350 & Mucous membrane & WS, HE & $\begin{array}{l}\text { Doxycycline, } \\
5 \text { days }\end{array}$ & $\mathrm{PR}$, no relapse \\
\hline 21 & 35 & M & $\mathrm{C} 3$ & 37 & $\begin{array}{l}\text { Skin, liver, spleen, } \\
\text { bone }\end{array}$ & WS, HE & $\begin{array}{l}\text { Erythromycin, } \\
7 \text { weeks }\end{array}$ & $\mathrm{CR}$, no relapse \\
\hline
\end{tabular}

WS = Warthin-Starry staining; $\mathrm{HE}=$ hematoxylin-eosin staining; $\mathrm{EM}=$ electron microscopy; $\mathrm{PCR}=$ polymerase chain reaction; $\mathrm{M}=\operatorname{man} ; \mathrm{W}=$ woman; $\mathrm{PR}=$ partial remission; $\mathrm{CR}=$ complete remission . 


\section{Discussion}

Despite the common occurrence of Bartonella infections with more than 40,000 cases of cat scratch disease each year in the USA, BA remains a rare disorder. The prevalence of $\mathrm{BA}$ in the presented study was 1.2 cases/ 1,000 HIV-infected patients. LeBoit [4] estimated 1 case of BA for every 25-50 afflictions with Kaposi's sarcoma. Under the assumption that Kaposi's sarcoma makes up about $20 \%$ of the manifestations in patients with AIDS, in our study population LeBoit's estimation would forecast 125-250 AIDS patients with BA. Considering the fact that the number of HIV-infected patients is about three times higher than of those with AIDS, LeBoit's estimations correspond quite well with our results. Nevertheless, presumably even today not all cases of BA are diagnosed and the implementation of antibiotic prophylactics (e.g. with cotrimoxazole or clarithromycin) considerably affects the incidence of BA. In accordance with Cockerell, we observed that most of the affected patients (90\%) had a severe immunosuppression with less than $100 / \mu 1$ CD4 cells [14]; however, 2 of the 21 patients had significantly more than $200 / \mu$ l CD4 lymphocytes.

A frequently recurring topic in the medical literature on BA is the question of pathogen transmission via cats. Tappero et al. [15] were able to show an association between the appearance of BA and previous scratching by cats. For various Bartonella infections, arthropods were able to be identified as vectors: $B$. bacilliformis is transmitted by sand flies, B. quintana by body lice and $B$. henselae by cat fleas $[5,16]$. Correspondingly, Koehler et al. $[5,17]$ and Gasquet et al. [18] discovered an association betwen $B$. quintana infections and homelessness or low social standard as well as between $B$. henselae infections and contact with cats. Even today, it is still not clear whether $B$. henselae is transmitted to humans via direct contact with cats or via the vector of the cat flea. In our study, previous traumatic or atraumatic contact with cats could only be verified for 11 of the 21 patients. Ten patients had no previous contact with cats while the only patient who owned a cat denied having any traumatic contact with the pet.

As many authors have already pointed out, our findings verified the skin as the most frequently affected organ $[19,20]$. In our study, $90 \%$ of the patients had lesions of the skin and $24 \%$ of the bones. Cockerell [14] states that infection of the bones occurs in 35\% of the cases.

Although antibiotic therapies had been initiated in all premortally diagnosed cases, the rate of complete remission in the described patients was only $70 \%$. The reasons for this poor outcome is probably the comparatively short duration of therapy, with an average of 35 days. The current medical literature recommends a treatment of 8-16 weeks [10]. This may also be the explanation for the high rate of relapses $(28 \%)$.

The work presented here was largely based on the diagnosis of BA by Warthin-Starry staining in combination with clinical findings. Molecular biological techniques, like PCR, which is today commonly used for verification and identification of pathogens, were for the most part not yet available at the time of the described BA cases [5]. Nevertheless, a high level of clinical suspicion remains the most important first step to the diagnosis of BA in HIVinfected patients.

\section{Acknowledgments}

We would like to thank the AIDS Center of the Robert Koch Institute/Bundesministerium für Gesundheit (file 415-4476-09/25) for their support. Additionally, we would like to extend our gratitude to the members of the German AIDS Study Group (GASG/IdkF) for their cooperation. Further thanks go to Dr. A. Sander from the Institut für Medizinische Mikrobiologie und Hygiene der Universität Freiburg for the molecular biological diagnostics (fig. 1d) and Prof. M. Tronnier from the Universitätshautklinik Lübeck for the electron microscopy (fig. 1c).

\section{Appendix}

Participating centers of the German AIDS Study Group (GASG/ IdkF): (1) Bernhard-Nocht-Institut für Tropenmedizin, Hamburg; (2) Medizinische Poliklinik am Universitätskrankenhaus Eppendorf, Hamburg; (3) Allgemeines Krankenhaus St. Georg, Hamburg; (4) Auguste-Viktoria-Krankenhaus, Berlin; (5) Klinik Steglitz der Benjamin-Franklin-Universität Berlin; (6) Krankenhaus Prenzlauer Berg, Berlin; (7) Abteilung Immunologie der Medizinischen Hochschule Hannover; (8) Zentrum für Innere Medizin, Göttingen; (9) Medizinische Klinik der Universität Düsseldorf; (10) Dermatologische Klinik der Universität Essen; (11) Klinik und Poliklinik für Dermatologie der Universität Köln; (12) Medizinische Universitätsklinik Bonn; (13) Zentrum für Dermatologie und Venerologie, Universität Frankfurt; (14) Zentrum für Innere Medizin der Universität Frankfurt; (15) Medizinische Klinik und Poliklinik der JohannGutenberg-Universität Mainz; (16) Medizinische Klinik und Poliklinik der Universität Saarland; (17) Universitätshautklinik Heidelberg; (18) Krankenhaus Schwabing, München; (21) Dermatologische Klinik und Poliklinik der Universität München; (22) Medizinische Poliklinik der Universität München; (23) Medizinische Klinik und Poliklinik der Universität Köln. 


\section{References}

1 Stoler MH, Bonfiglio TA, Steigbigel RT, Pereira $\mathrm{M}$ : An atypical subcutaneous infection associated with acquired immune deficiency syndrome. Am J Clin Pathol 1983;80:714-718.

2 Cockerell CJ, Bergstresser PR, Myrie-Williams C, Tierno PM: Bacillary epithelioid angiomatosis occurring in an immunocompetent individual. Arch Dermatol 1990;126:787-790.

3 Tappero JW, Koehler JE, Berger TG, Cockerell CJ, Lee TH, Busch MP, Stites DP, Mohle-Boetani J, Reingold AL, LeBoit PE: Bacillary angiomatosis and bacillary splenitis in immunocompetent adults. Ann Intern Med 1993;118 363-365.

4 LeBoit PE: Bacillary angiomatosis. Mod Pathol 1995;8:218-222.

5 Koehler JE, Sanchez MA, Garrido CS, Whitfeld MJ, Chen FM, Berger TG, Rodriguez-Barradas $\mathrm{MC}$, LeBoit $\mathrm{PE}$, Tappero JW: Molecular epidemiology of Bartonella infections in patients with bacillary angiomatosis-peliosis. N Engl J Med 1997;337:1876-1883.

6 Schmincke A: Histopathologischer Befund in Roseolen der Haut bei Wolhynischem Fieber. Münch Med Wochenschr 1917;64:91.

7 Relman DA, Loutit JS, Schmidt TM, Falkow S, Tompkins LS: The agent of bacillary angiomatosis: An approach to the identification of uncultured pathogens. N Engl J Med 1990;323: 1573-1580.
8 Koehler JE, Quinn FD, Berger TG, LeBoit PE, Tappero JW: Isolation of Rochalimaea species from cutaneous and osseous lesions of bacillary angiomatosis. N Engl J Med 1992;327:16251631.

9 Cockerell CJ, Whitlow MA, Webster GF, Friedman-Kien AE: Epithelioid angiomatosis: A distinct vascular disorder in patients with the acquired immunodeficiency syndrome or AIDS-related complex. Lancet 1987;ii:654656

10 Koehler JE, LeBoit PE, Egbert BM, Berger TG: Cutaneous vascular lesions and disseminated cat-scratch disease in patients with the acquired immunodeficiency syndrome (AIDS) and AIDS-related complex. Ann Intern Med 1988;109:449-455.

11 Hettmannsperger U, Soehnchen R, Gollnick H, Detmar M, Orfanos CE: Bazilläre epithelioide Angiomatose bei fortgeschrittener HIVInfektion. Hautarzt 1993;44:803-807.

12 Schneider T, Ullrich R, Schmitt-Gräff A, Bergs C, Reiterer L, Dissmann T, Zeitz M, Riecken EO: Bacillary angiomatosis in a German patient with AIDS: Case report. Clin Invest 1993; $72: 50-54$
13 Plettenberg A, Tronnier M, Kreusch J, Wolff $\mathrm{HH}$, Meigel W: Bazilläre Angiomatose. Hautarzt 1995;46:39-43.

14 Cockerell CJ: Bacillary angiomatosis and related diseases caused by Rochalimaea. J Am Acad Dermatol 1995;32:783-779.

15 Tappero JW, Mohle-Boetani J, Koehler JE, et al: The epidemiology of bacillary angiomatosis and bacillary peliosis. JAMA 1993;269:770775 .

16 Chomel BB, Kasten RW, Floyd-Hawkins K: Experimental transmission of Bartonella henselae by the cat flea. J Clin Microbiol 1996;34: 1952-1956.

17 Koehler JE, Glaser CA, Tappero JW: Rochalimaea henselae infection: A new zoonosis with the domestic cat as reservoir. JAMA 1994;27: 531-535.

18 Gasquet S, Maurin M, Brouqui P, Lepidi H, Raoult D: Bacillary angiomatosis in immunocompromised patients. AIDS 1998;12:17931803.

19 Berger TG, Koehler JE: Bacillary Angiomatosis. AIDS Clin Rev 1993-1994:43-60.

20 Koehler JE, Tappero JW: Bacillary angiomatosis and bacillary peliosis in patients infected with human immunodeficiency virus. Clin Infect Dis 1993;17:612-624. 